\title{
Molecular Signaling in Tumorigenesis of Gastric Cancer
}

\author{
Fatemeh Molaei ${ }^{1}$, Mohammad Mahdi Forghanifard ${ }^{2}$, Yasaman \\ Fahim $^{1}$ and Mohammad Reza Abbaszadegan ${ }^{3^{*}}$
}

${ }^{1}$ Immunology Research Center, Mashhad University of Medical Sciences, Mashhad, Iran; ${ }^{2}$ Department of Biology, Damghan Branch, Islamic Azad University, Damghan, Iran; ${ }^{3}$ Medical Genetics

Research Center, Mashhad University of Medical Sciences, Mashhad, Iran

Received 2 December 2017; revised 28 January 2018; accepted 3 February 2018

\begin{abstract}
Gastric cancer $(G C)$ is regarded as the fifth most common cancer and the third cause of cancer-related deaths worldwide. Mechanism of GC pathogenesis is still unclear and relies on multiple factors, including environmental and genetic characteristics. One of the most important environmental factors of GC occurrence is infection with Helicobacter pylori that is classified as class one carcinogens. Dysregulation of several genes and pathways play an essential role during gastric carcinogenesis. Dysregulation of developmental pathways such as $\mathrm{Wnt} / \beta$-catenin signaling, Hedgehog signaling, Hippo pathway, Notch signaling, nuclear factor-kB, and epidermal growth factor receptor have been found in GC. Epithelial-mesenchymal transition, as an important process during embryogenesis and tumorigenesis, is supposed to play a role in initiation, invasion, metastasis, and progression of GC. Although surgery is the main therapeutic modality of the disease, the understanding of biological processes of cell signaling pathways may help to develop new therapeutic targets for GC. DOI: 10.22034/ibj.22.4.217
\end{abstract}

Keywords: Beta Catenin, Epithelial-mesenchymal transition, Hedgehogs, Helicobacter pylori, NF-kappa B

Corresponding Author: Mohammad Reza Abbaszedagan

Medical Genetics Research Center, Mashhad University of Medical Sciences, Mashhad, Iran; Tel. \& Fax: (+98-21) 7112343;

E-mail: abbaszadeganmr@mums.ac.ir

\section{INTRODUCTION}

$\mathrm{G}$ astric cancer (GC) is one of the most common and lethal cancers worldwide. More than 950,000 new cases are diagnosed annually ${ }^{[1]}$. The incidence of GC is higher in Eastern Asia, Eastern Europe, and Southern America than Northern America and Northern Africa ${ }^{[2]}$. In Iran, GC is prevalent in northern and northwestern regions, and men are twice as likely to be affected than women ${ }^{[3]}$. GC is the fourth most common cancer (after lung, prostate, and colorectal cancers) in men and the fifth most common cancer (after breast, cervical, colorectal, and lung cancers) in women globally ${ }^{[4]}$. Despite the declining rate of GC incidence and advances in diagnosis, GC causes more than 700,000 death annually, and a fiveyear survival rate is nearly $20 \%{ }^{[5]}$.

Gastric adenocarcinoma has recently been classified genetically to four molecular subtypes, including chromosomal instability, microsatellite instability, genome stable, and Epstein-Barr virus-positive ${ }^{\left[\left[{ }^{[6]}\right.\right.}$. There are two main histological types of GC consisting of intestinal and diffuse types. Development of the intestinal type includes the transformation of normal mucosa to the similar mucosa of the intestinal epithelium. These series of mucosal alterations are triggered by chronic inflammation (gastritis), which eventually leads to metaplasia, dysplasia, and cancer. The diffuse type appears as single-cell that changes in the mucous neck area of gastric glands ${ }^{[7]}$. Thirty to $50 \%$ of the diffuse types are caused by either point or small frameshift mutations in $\mathrm{CDH} 1$ gene, which encodes E-cadherin and plays an essential role in cell adhesion $^{[8]}$.

Some of the main risk factors of GC are summarized in Table 1, including Helicobacter pylori infection and atrophic gastritis, tobacco smoking, dietary salt and food preservation, pernicious anemia, and 
Table1. GC risk factors

\begin{tabular}{|c|c|c|}
\hline GC risk factor & Explanations & Reference \\
\hline H. pylori infection & $\begin{array}{l}\text { Most important risk factor, long-term infection, leads to chronic atrophic } \\
\text { gastritis and pre-cancerous alterations. The international agency for research on } \\
\text { cancer (IARC) classified } H \text {. Pylori as the first class carcinogen. People with GC } \\
\text { have a higher rate of } H \text {. pylori infection. }\end{array}$ & [105] \\
\hline Smoking & $\begin{array}{l}\text { Smoking increased the risk of GC. Studies have reported that smokers have } \\
\text { higher hazard ratio in GC in cardia }(2.86-4.10) \text { compared with the distal region } \\
\text { of stomach }(1.52-1.94) \text {. }\end{array}$ & {$[106]$} \\
\hline E-cadherin gene & $\begin{array}{l}\text { Hereditary diffuse } \mathrm{GC} \text { caused by the mutation in } \mathrm{CDH} 1 \text { gene encodes E- } \\
\text { cadherin. }\end{array}$ & [107] \\
\hline Pernicious anemia & $\begin{array}{l}\text { People with Pernicious anemia have increased the risk of GC. More studies are } \\
\text { needed to confirm this condition. }\end{array}$ & [9] \\
\hline Diet & $\begin{array}{l}\text { Diet play important role in prevention and development of GC. Salt and salt- } \\
\text { preserved foods increased the risk of GC. Intake twice or more of fruits and } \\
\text { vegetables in a day decreased the risk of GC. }\end{array}$ & [7] \\
\hline Epstein-Barr virus (EBV) & $\begin{array}{l}5 \% \text { to } 10 \% \text { of GCs are associated with EBV. Its mechanism is DNA } \\
\text { methylation (gene silencing). }\end{array}$ & [108] \\
\hline
\end{tabular}

abnormalities in E-cadherin gene ${ }^{[9]}$. The aim of this review is to summarize several important signaling pathways in GC, which helps to have a better understanding of GC biology.

\section{Molecular pathways of GC}

There are several cell signaling pathways playing a role in gastric carcinogenesis. Here, we review different cell signaling pathways that are involved in GC tumorigenesis, highlighting either the expression pattern or contributed mutations in related genes.

\section{Hedgehog (Hh) signaling pathway}

The Hh signaling pathway is important in embryonic
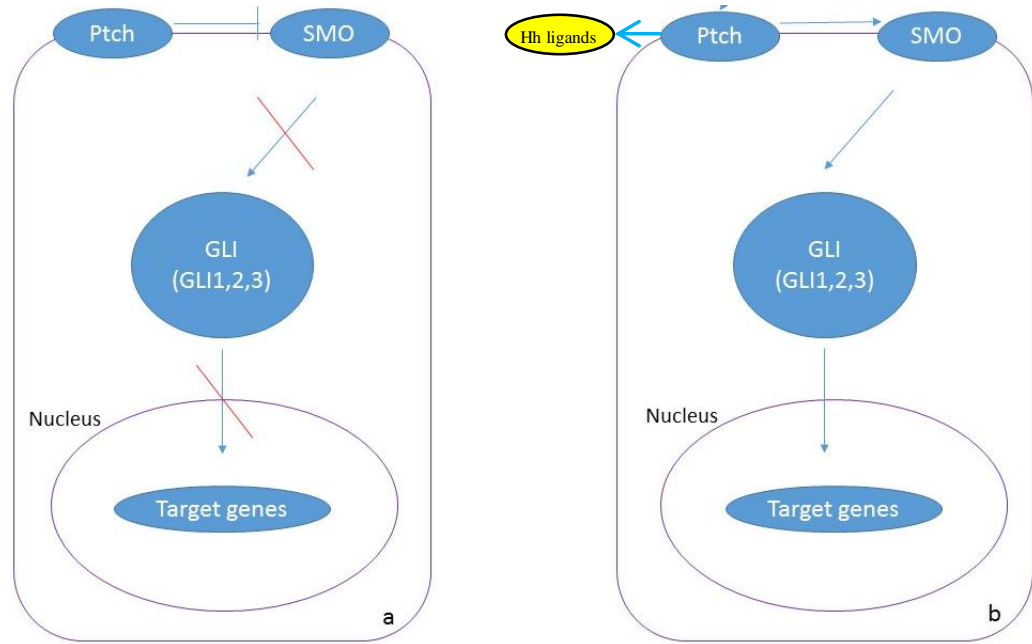

Fig. 1. Hh pathway in Hh signaling. In the absence of ligands Ptch inhibits SMO and then inactivates the signaling pathway (a). (b) In the presence of ligands, ligands bind to the Ptch, and the activation of SMO and signaling pathway occurs (b).

development, differentiation, proliferation, and maintenance of some adult tissues. Ligands of this pathway in mammals include Sonic, Indian, and Desert. In the absence of these ligands, the transmembrane receptor ptch inhibits another transmembrane protein (smoothened [SMO]), resulting in deactivation of Hh pathway. By binding ligands to the ptch receptor, the inhibitory effect of patch is eliminated from SMO, and SMO activates the downstream transcription factors, including GLI (GLI1, GLI2, and GLI3) proteins. Then GLI translocates to the nucleus and activates Hh-related target genes $^{[10]}$ (Fig. 1). 
In the gastrointestinal tract, where epithelial cells are continuously replenished from progenitor cell populations, Hh signaling appears to be essential for restoration. During GC processing, chronic H. pylori infection causes mucosal damage. Furthermore, the overexpression of sonic $\mathrm{Hh}$ has been detected in progenitor cells (in gastric mucosa), which restore the damaged gastric mucosa ${ }^{[11]}$. In addition, overexpression of GLII was correlated to the lymph node metastasis in esophageal squamous cell carcinoma (ESCC) patients ${ }^{[12]}$. The expression changes of this pathway in GC are summarized in Table 2.

\section{Wnt/ק-catenin pathway}

Wnt proteins are cysteine-rich glycoproteins that bind to the extracellular domain of frizzled receptor and lipoprotein receptor-related protein 5/6. Wnt signaling regulates different cellular processes, including cell fate, movement, polarity, and organogenesis. There are three types of Wnt pathways. The first is canonical or $\beta$-catenin-dependent pathway that involves in the stabilization of the proto-oncogene $\beta$-catenin. The second is planar cell polarity pathway that involves in cell ciliogenesis. The last is $\mathrm{Wnt} / \mathrm{Ca} 2+-$ dependent pathway that stimulates the intracellular release of calcium and activates $\mathrm{Ca} 2+$-dependent mediators controlling cell movement and behavior. The planar cell polarity and $\mathrm{Wnt} / \mathrm{Ca} 2+$ pathways are collectively called either non-canonical or $\beta$-cateninindependent pathway ${ }^{[13]}$

In the absence of Wnt, GSK3 in APC complex (including APC, AXIN, CK1, and GSK3) phosphorylates $\beta$-catenin, which in turn leads to the degradation of $\beta$-catenin in proteasome complex. Binding of Wnt ligand to the frizzled receptor inhibits GSK3 activity through dishevelled, resulting in dephosphorylation and stabilization of the $\beta$-catenin. Therefore, $\beta$-catenin accumulates in the nucleus, and its interaction with the T-cell factor/lymphoid enhancer factor (TCF/LEF) transcription factor family stimulates the transcription of Wnt target genes ${ }^{[14]}$. Two signaling pathways, including nuclear factor (NF)-kB and $\mathrm{Wnt} / \beta$-catenin are dysregulated in $70 \%$ of the GC patients ${ }^{[15]}$. Wnt pathway is a key element in cell proliferation during both normal and cancerous gut development. SALL4, as an embryonic stem cell marker, has a direct interaction with Wnt signaling. Its overexpression is correlated with lymph node metastasis in $\mathrm{GC}^{[16]}$. Furthermore, overexpression of SALL4 and SOX2, members of the sex-determining region Y-related high-mobility group (HMG), are observed in ESCC, and the expression levels of these two genes are correlated with each other ${ }^{[17]}$. The overexpression of SALL4 has also been detected in patients with colorectal cancer, and its overexpression is associated with the grade of tumor cell differentiation and tumor cell metastasis to the lymph node ${ }^{[18]}$. Some of the genetic alterations of this pathway are summarized in Table 3 .

H. pylori infection dysregulates Wnt signaling pathway. CagA, the most important virulence factor of $H$. pylori, causes the activation of the $\beta$-catenin through an independent phosphorylation manner. CagA interacts with E-cadherin, leading to $\beta$-catenin accumulation in cytoplasm and nucleus. Moreover, CagA transactivates $C D X 1$ and $P 21$ genes that are involved in the intestinal differentiation of gastric epithelial cells ${ }^{[19]}$. VacA, another $H$. pylori virulence factor, induces $\mathrm{Wnt} / \beta$-catenin signaling through the activation of PI3K/Akt pathway, resulting in phosphorylation of GSK $3 \beta$ and translocation of the $\beta$ catenin to the nucleus to activate CCNDI gene ${ }^{[20]}$. Moreover, $H$. pylori infection increases the expression levels of Oct 4 and Nanog, two cancer stem cell (CSC) markers, through Wnt signaling that promotes CSCproperties in GC cells ${ }^{[21]}$.

Table 2. Hh pathway

\begin{tabular}{|c|c|c|}
\hline Up-regulated genes & Explanations & Reference \\
\hline$S H H, P T C H$, and $G L I I$ & $\begin{array}{l}\text { Up-regulation of these genes is observed during } H \text {. pylori infection in GC cells. } \\
\text { CagA-positive } H \text {. pylori was correlated with the higher expression of } S H H \text {. }\end{array}$ & {$[11]$} \\
\hline $\begin{array}{l}P T C H 1, S M O, \text { and } G L I \\
\text { Shh and } I h h\end{array}$ & $\begin{array}{l}\text { Overexpression of these genes is documented in diffuse types of GC. Expression of } \\
\text { Shh and Ihh is detected in the intestinal type of GC. }\end{array}$ & [109] \\
\hline GLII & $\begin{array}{l}\text { The up-regulation of Glil and down-regulation of } S u F u \text { have been reported in GC } \\
\text { tissue. Glil overexpression is correlated with aggressive phenotype. }\end{array}$ & {$[110]$} \\
\hline SHH & $\begin{array}{l}\text { SHH overexpression is related with age, tumor differentiation state, T staging, and N } \\
\text { stage in GC. In another study, } S H H \text { expression is correlated with lymphatic metastasis } \\
\text { and poor prognosis. Furthermore, in xenograft of human GC, the up-regulation of } \\
\text { SHH significantly enhances the incidence of lung metastasis. }\end{array}$ & [111] \\
\hline$S H H, P T C H$, and Gli3 & $\begin{array}{l}\text { The expression of these genes increases in CD } 44+\text { and CD } 24+\text { subpopulation, which } \\
\text { is comparable with the CD } 44-\text { CD } 24-\text { subpopulation. }\end{array}$ & [112] \\
\hline
\end{tabular}


Table 3. Genetic alteration of Wnt pathway

\begin{tabular}{|c|c|c|c|}
\hline Gene & Genetics alteration & Explanation & Reference \\
\hline Wnt-1 & Up-regulated & & {$[113]$} \\
\hline Wnt-2 & Up-regulated & $\begin{array}{l}\text { The overexpression of } W N T 2 \text { is correlated with cytoplasmic/nuclear } \\
\beta \text {-catenin accumulation in both intestinal- and diffuse-type ofr GC in } \\
\text { Chinese people. Moreover, the expression of } W N T 2 \text { positively is } \\
\text { correlated with lymph node metastasis. }\end{array}$ & [114] \\
\hline Wnt-5 & Up-regulated & Its expression is correlated with poor prognosis. & [115] \\
\hline$F z d-3$ & Up-regulated & $\begin{array}{l}\text { Its overexpression is correlated with the activation of Wnt signaling } \\
\text { in GC. }\end{array}$ & [116] \\
\hline$C T N N B 1$ & Mutation & $\begin{array}{l}\text { Mutation in the gene }(C T N N B 1) \text { is found in diffuse and intestinal } \\
\text { type of GC. }\end{array}$ & [117] \\
\hline$T C F 7 L 2$ & Somatic frame shift mutation & $\begin{array}{l}\text { Somatic frame shift mutation is detected in GC with microsatellite } \\
\text { instability. }\end{array}$ & [118] \\
\hline$A P C$ & Mutation & Mutation and deletion & [119] \\
\hline Sox10 & Down-regulated & Sox10 is a transcription factor that regulates Wnt signaling. & [120] \\
\hline WNT10A & Up-regulated & H. Pylori infection induces this overexpression. & [121] \\
\hline
\end{tabular}

Transglutaminase (TGM) family plays an essential factor in drug resistance and progression of cancers. The expression level of TGM1, a member of TGM family, is elevated in GC that indicates TGMI participation in the development of this disease. Moreover, the reduced levels of TGMI in GC cells result in the suppression of Wnt signaling activities. This result suggests that the TGM1 may function in GC by affecting Wnt signaling pathway ${ }^{[22]}$.

\section{Cell cycle}

Dysregulation of the cell cycle components is a defining factor in gastric tumorigenesis. Activation of the cyclin-dependent kinase $(\mathrm{CDK})$ results in cell cycle progression. Cyclin D1 and cyclin D2 are up-regulated in $\mathrm{GC}^{[23]}$. Furthermore, cyclin D1 is up-regulated in cocultured GC cells with $H$. pylori infection ${ }^{[24]}$.

Tp53, the guardian of human genome, is a tumor suppressor gene that is commonly mutated in all types of human cancer. TP53 gene mutation is observed in $\mathrm{GC}^{[25]}$. Moreover, P21Waf1/Cip1, as a target for $\mathrm{p} 53$, binds to cyclin A-CDK2 and cyclin D1-CDK4 complexes and inhibits their function. Loss of P21Waf1/Cip1 expression has been reported in the $60 \%$ of GC tissues. Moreover, the underexpression of $\mathrm{P} 21 \mathrm{Waf} 1 / \mathrm{Cip} 1$ is correlated with tumor invasiveness and metastasis, as well as poor prognosis in $\mathrm{GC}^{[26]}$. Besides, down-regulation of p27Kip1, a CDK inhibitor, has been observed in GC, and its downregulation is correlated with advanced stages and invasiveness of the tumor ${ }^{[27]}$.

$\mathrm{P} 16$ is a regulator of cell cycle that causes G1 phase arrest by the inhibition of CDK4 and CDK6. The expression of P16 is observed in tissues and serum of GC patients, while its expression is not detected in normal tissues and sera. P16 DNA methylation can be used as a serum biomarker for early detection of $\mathrm{GC}^{[28]}$.

\section{Notch signaling}

Notch signaling is an important pathway in tumorigenesis through the regulation of cell proliferation, apoptosis, and differentiation. Jagged 1 is a ligand of Notch signaling. After binding Jagged1 to the Notch receptor, Notch1 receptor intracellular domain is cleaved by matrix metalloproteinase (MMP) and $y$-secretase and consequently translocates into the nucleus to activate transcription machinery ${ }^{[29]}$.

$H$. pylori infection can induce Notch signaling. Moreover, jagged1 expression is associated with aggressiveness of GC. Notch signaling induces expression of the cyclooxygenase-2 (COX-2) through the binding of the Notch1 receptor intracellular domain to the Cox-2 promoter, which results in GC progression $^{[30]}$. The expression of Notch 1 is detected in human GC, especially in well-differentiated intestinal type $^{[31]}$. Furthermore, up-regulation of Notch1, Notch3, Jagged1, and Jagged 2 are significantly correlated with the intestinal type of $\mathrm{GC}^{[32]}$. In addition, inhibition of Notch signaling pathway in GC leads to the activation of PTEN, which consequently induces $\mathrm{G} 2 / \mathrm{M}$ cell cycle $\operatorname{arrest}^{[33]}$. Overexpression of Notch signaling target genes, such as $H E Y 1$ and $H E Y 2$, has been reported in ESCC with significant correlation to the different 
indices of poor prognosis, including stage of tumor progression and lymph node metastasis ${ }^{[34]}$.

\section{Hippo signaling}

The Hippo signaling pathway is a key element in cell growth and organ size, as well as in the homeostasis of the gastrointestinal tissues. Moreover, dysregulation of Hippo pathway is associated with initiation, development, and distant metastasis of $\mathrm{GC}^{[35]}$. The main components of this pathway are MST1/2, LATS1/2, Mob1, YAP1, and TAZ1. MST1/2 phosphorylates and activates LATS1/2 and Mob1. Then LATS1/2 phosphorylates YAP1 and TAZ and increases 14-3-3 binding to phosphorylated YAP1/TAZ, leading to the oncogenic accumulation of the YAP1/TAZ in the cytoplasm. The unphosphorylated YAP1/TAZ translocates to the nucleus and binds to the TEAD1-4 transcription factors to induce transcriptional activity for cell growth and differentiation $^{[36]}$ (Fig. 2).

While the down-regulation of upstream components of Hippo pathway, such as MST1/2 and LATS1/2, is detected in GC, up-regulation of YAP1 that is the main downstream component is observed in high-grade dysplasia and metastatic $\mathrm{GC}^{[37]}$. Moreover, YAP1 is negatively regulated by tumor suppressor microRNAs, including miR-15a, miR-16-1, and miR-506 in GC ${ }^{[38]}$. The gain of function mutation in RhoA, an activator of YAP1, has been detected in diffuse type of $\mathrm{GC}^{[39]}$. TEAD4 gene, as the main transcription factor of this pathway, is significantly hypo-methylated, and its overexpression is observed in $\mathrm{GC}^{[40]}$. Furthermore, the expression of TAZ, another key effector of the Hippo pathway, is associated with the overexpression of $\beta$ catenin and poor prognosis in $\mathrm{GC}^{[41]}$.

\section{Epithelial-mesenchymal transition (EMT)}

EMT is a cellular process that normally occurs during heart morphogenesis, mesoderm and neural crest formation, embryogenesis, wound healing, as well as fibrotic disease and cancer ${ }^{[42]}$. There are three types of EMT process. The type one of EMT is involved in generating mesenchymal cells; these cells can undergo a MET process to produce secondary epithelial cells. Actually, this type of EMT plays a role during embryogenesis and organ development. The type two of EMT involves in wound healing and tissue reconstruction and organ fibrosis. Moreover, type two is an essential factor during inflammation. The type three of EMT has a key role in neoplastic cells; these cells have enormous genetic and epigenetic changes, especially in oncogenes and tumor suppressor genes. Those neoplastic cells that undergo the type three of EMT may invade and metastasize, thereby leading to cancer progression $^{[43]}$. Through the EMT process, cell phenotype changes from epithelial to mesenchymal. Indeed, epithelial cells lose their cell-cell adhesion, alter their polarity, rearrange their cytoskeleton and become isolated $^{[44]}$.
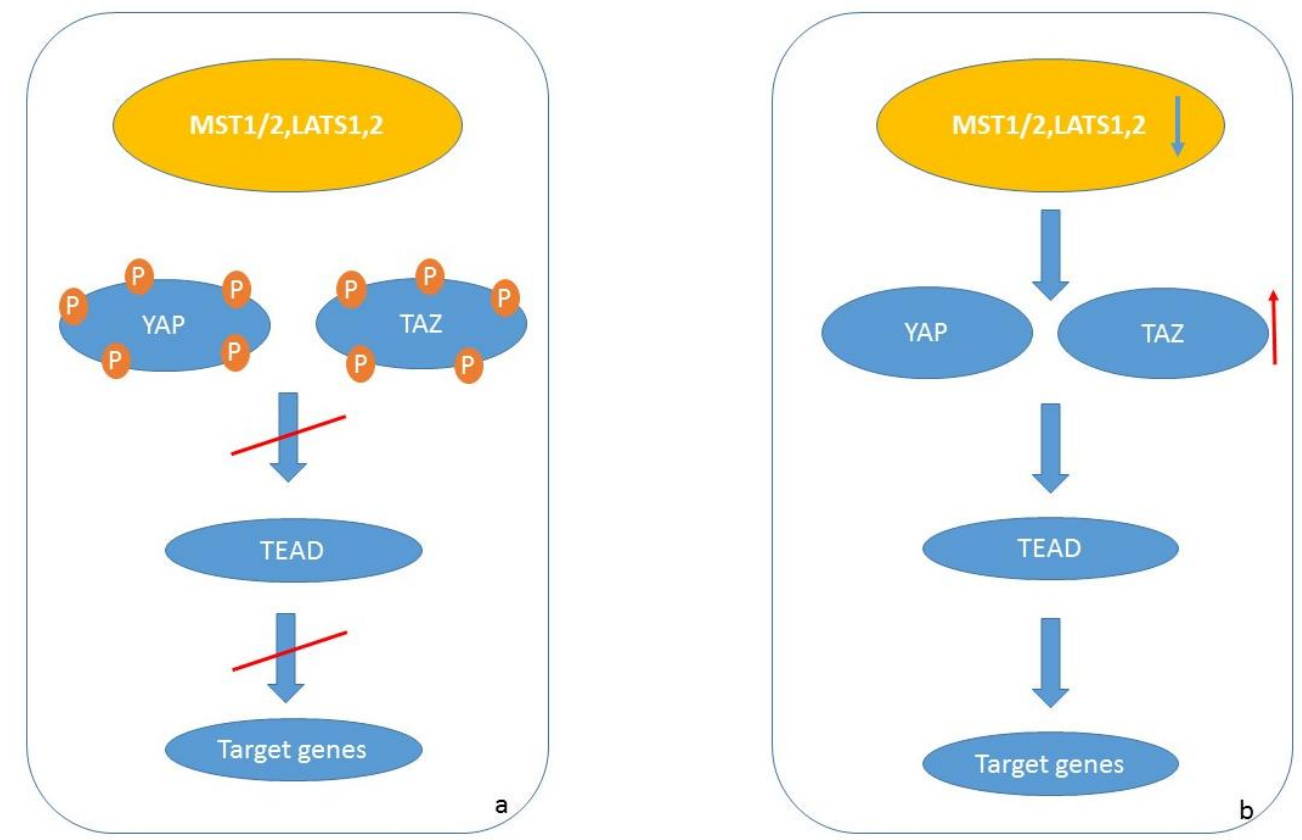

Fig. 2. Hippo pathway. (a) During signaling pathway; the upstream components (MST1/1, LATS1/2) phosphorylate the downstream components and result in inactivation of pathway. (b) During GC; the expression of MST1/2 and LATS1/2 decreased and failed to phosphorylate YAP/TAZ. YAP/TAZ translocates to the nucleus and binds to the TEAD, resulting in transcription of target genes. 
During EMT process, the down-regulation of Ecadherin, which is essential for the cell adhesion and is expressed at the surface of the epithelial cells, occurs. Moreover, the overexpression of $\mathrm{N}$-cadherin, which is expressed in the mesanchymal cells, is another important event in $\mathrm{EMT}^{[45]}$. Other proteins such as FSP1, $\beta$-catenin, $\alpha$-SMA, extracellular matrix (ECM), and cytoskeleton proteins are also determinant in EMT progress ${ }^{[46]}$. Besides, WNT5A induces EMT-related genes in GC and probably regulats EMT process ${ }^{[47]}$. In addition, paired-related homeobox 1 is up-regulated in GC. Additionally, PRPX1 induces EMT through the activation of the Wnt/B-catenin pathway ${ }^{[48]}$. Furthermore, the overexpression of the Twist1, a regulatory protein of EMT, and Vimentin as well as PDCD4 and E-cadherin downregulation have been detected in GC samples. Moreover, CagA transfection into GC cells can activate TWIST1 and Vimentin. Besides, CagA can decrease the expression levels of the E-cadherin through the down-regulation of the PDCD $4^{[49]}$. Down-regulation of the Twist1 is associated with the up-regulation of the E-cadherin, suggesting that Twist1 induces EMT in $\mathrm{GC}^{[50]}$. Furthermore, the expression of the erythropoietinproducing hepatocellular A2 is positively associated with the EMT markers in $\mathrm{GC}^{[51]}$. Moreover, Fas signaling induces EMT and increases metastasis in GC. During the progression of $\mathrm{GC}$, the overexpression of the FasL, phospho-GSK-3 $\beta$, Snail, and B-catenin is observed $^{[52]}$.

The overexpression of the transforming growth factor beta (TGF- $\beta 1)$, Twist1, Snail, Slug, and Vimentin, as well as CD44, which is a CSC marker, is found in patients with dysplasia or early GC. Moreover, the expression levels of E-cadherin, an epithelial marker, decreased. Furthermore, eradication of the H. pylori infection decreased the levels of the TGF- $\beta 1$, Twist, Snail, Slug, and Vimentin, while the levels of the E-cadherin increased. These data suggests that $H$. pylori may induce EMT through TGF- $\beta 1^{[53]}$.

EMT is a key factor in gastric tumorigenesis. GC stem cells are significantly correlated with the expression of the EMT activating transcription factors. Moreover, CD44 expression is significantly associated with the expression of the Snail-1, ZEB-1, and Ecadherin in $\mathrm{GC}^{[54]}$. Overexpression of MAML1 and TWIST1 is significantly correlated with lymph node metastasis in ESCC patient ${ }^{[55]}$. Furthermore, the expression levels of TWIST1 and SNAIL genes are significantly correlated with invasion in ESCC cell line KYSE-30 where ectopic expression of TWIST1 results in the significant down-regulation of $S N A I L^{[56]}$. Some of the important factors of EMT have been summarized in Table 4.

\section{Matrix metalloproteinase}

MMPs) break down the components of the ECM. MMPs and their tissue inhibitors act in tumor invasion and metastasis. The levels of the MMPs and tissue inhibitors increased in $\mathrm{GC}^{[57]}$. Besides, the overexpression of MMP9 in GC is associated with tumor invasion, and its serum level has a relation with the lymph node metastasis. Therefore, this data suggests that MMP9 is a novel biomarker for diagnosis and prognosis of $\mathrm{GC}^{[58]}$. The overexpression of $M M P 2$, $M M P 7$, and $M M P 9$ has also been observed in $\mathrm{GC}^{[59]}$. Interestingly, the expression of MMP1 is associated with the metastasis of GC cells ${ }^{[60]}$. Expression of the integrin $\alpha v \beta 6$, which is an epithelial-specific receptor for fibronectin (an ECM protein), is associated with MMP9 in $\mathrm{GC}^{[61]}$.

Table 4. EMT factors

\begin{tabular}{|c|c|c|c|}
\hline Gene & Function & Cancer & Reference \\
\hline E-Cadherin & $\begin{array}{l}\text { Cell adhesion } \\
\text { Expressed in epithelial cell }\end{array}$ & $\begin{array}{l}\text { During EMT, the loss of E-cadherin expression } \\
\text { occurs. }\end{array}$ & [122] \\
\hline$N$-Cadherin & Expressed in mesenchymal cells & $\begin{array}{l}\text { Gain of N-Cadherin expression during EMT } \\
\text { occurs. }\end{array}$ & [122] \\
\hline TWIST1 & $\begin{array}{l}\text { A transcription factor induces EMT and } \\
\text { increases metastasis }\end{array}$ & Overexpression in GC and EMT happens. & [123] \\
\hline SNAIL & $\begin{array}{l}\text { Transcription factor that controls EMT } \\
\text { during embryogenesis and tumorigenesis }\end{array}$ & $\begin{array}{l}\text { Its expression is associated with tumorigenesis in } \\
\text { GC during EMT. }\end{array}$ & [124] \\
\hline$Z E B-1$ & $\begin{array}{l}\text { A transcription factor that induces EMT and } \\
\text { metastasis }\end{array}$ & It overexpressed in GC. & [125] \\
\hline Vimentin & Mesenchymal marker in EMT & Its overexpression is observed in GC during EMT. & [126] \\
\hline Slug & Regulator of EMT & It overexpressed in GC. & [127] \\
\hline
\end{tabular}




\section{TGF- $\beta$ signaling pathway}

TGF- $\beta$ signaling pathway involves in many cellular processes such as cell growth, cell differentiation, and apoptosis. This pathway has many ligands, including TGF- $\beta$, activin, inhibin, bone morphogenetic proteins, Nodal, and others ${ }^{[62]}$. Furthermore, this pathway has two receptors: type I and type II, which are serine/threonine kinase receptors. During signaling, the ligands bind to the type II receptor where it catalyzes and phosphorylates the type I receptor. Then type I receptor phosphorylates SMADs proteins such as SMAD2/3; these proteins heterodimerize with SMAD4 and translocate into the nucleus to activate the transcription of target genes ${ }^{[63]}$. Dysregulation of the components of this pathway occurs in GC. The overexpression of TGF- $\beta 1$ is detected in $\mathrm{GC}^{[64]}$. Besides, its expression is associated with lymph node metastasis ${ }^{[65]}$. Moreover, the polymorphism $-509 \mathrm{C}>\mathrm{T}$ in the promoter region of $T G F-\beta 1$ has a connection with worse prognosis in $\mathrm{GC}^{[64]}$. RUNX3 is one of the target proteins in TGF signaling that is a defining factor in induction of apoptosis in GC cells and its inactivation has been found in $\mathrm{GC}^{[66]}$. Furthermore, $H$. pylori infection leads to the methylation of RUNX3 and inhibits its expression in $\mathrm{GC}^{[67]}$. Moreover, inactivation of SMAD4 has been reported in $\mathrm{GC}^{[68]}$. Additionally, mutations in TGF $\beta R I I$ occur in GC tissues, which are likely the result of microsatellites' instability. TGFBRII gene has 10 poly-A repeats that make them as hotspot regions for mutation ${ }^{[69]}$. Besides, mutations in $T G F \beta R I$ are less frequent in $\mathrm{GC}$, andits downregulation is associated with poor prognosis ${ }^{[70]}$.

\section{Cyclooxygenase-2 and lipoxygenase (LOX) pathways}

COX-2/ Prostaglandin E2 is one of the important pathways during gastric carcinogenesis. The COX enzymes, COX-1 and COX-2, are key effectors in prostaglandin synthesis. COX-1 has a function in the maintenance of the gastric mucosa integrity, while COX-2 is an inducible enzyme and can produce the prostaglandins. Prostaglandins are necessary for the reactions during the inflammatory processes. The normal mucosa of gastric produces COX-1, but the expression level of COX-2 is too low or undetectable. Moreover, COX-2 takes part in inflammation and carcinogenesis $^{[71]}$. Many studies have reported the overexpression of COX-2 in $\mathrm{GC}^{[72-74]}$. Besides, the $H$. pylori infection may induce the expression of $\mathrm{COX}-2$ in GC. H. Pylori infection induces the COX2 expression through p38 mitogen-activated protein kinase/activating transcription factor-2 signaling pathway in MKN45 GC cells ${ }^{[75]}$. Therefore, this pathway could be a novel therapeutic target for patients who have $H$. pylori-associated GC. Furthermore, $H$. pylori leads to the overexpression of vascular endothelial growth factor (VEGF) in MKN45 cells, which may be mediated by $\mathrm{COX}-2^{[76]}$. Moreover, the correlation between $C O X-2$ expression and $V E G F$ expression has been reported in GC, suggesting the important role of prostaglandins in gastric carcinogenesis $^{[77]}$. Additionally, COX-2 regulates the expression of Snail through Notch signaling pathway. The COX-2 expression has an inverse correlation with the Notch1 expression in GC cells ${ }^{[78]}$.

LOX pathway is an important pathway in producing leukotrienes and hydroxyeicosatetraenoic acids from arachidonic acid ${ }^{[79]}$. This pathway is also dysregulated during gastric carcinogenesis. In addition, 12-LOX is important during tumorigenesis. Its expression is found in GC cells, including AGS and MKN-28. Furthermore, 12-LOX regulates the apoptosis and cell proliferation in GC cells, and blocking the activity of 12-LOX leads to the inhibition of cell growth and activation of apoptosis ${ }^{[80,81]}$. Furthermore, the overexpression of LOX-5 has been reported in GC where its expression is associated with lymph node metastasis and TNM staging of the tumor $^{[82]}$. Moreover, during $\mathrm{H}$. Pylori infection, the activity of 5LOX and the amount of 5-hydroxyeicosatetraenoic acid, which is the product of the function of 5-LOX on arachidonic acid, increased in GC cells ${ }^{[83]}$. Besides, the inhibition of 5-LOX led to the activation of apoptosis in $\mathrm{GC}$ cells ${ }^{[84]}$.

\section{Epidermal growth factor receptor (EGFR), Human epidermal growth factor receptor 2 (HER2) signaling pathway}

EGFR, a member of Erb-B family receptors, has a role in gastric mucosa proliferation and development of $\mathrm{GC}$, and its overexpression is associated with poor prognosis in $\mathrm{GC}^{[85]}$. Furthermore, the overexpression and amplification of HER2, another member of ErbB family, has been detected in $\mathrm{GC}^{[86]}$.

One of the downstream components of HER2 and EGFR pathways is Ras, an oncogenic GTPase that has three isoforms, including K-Ras, H-Ras, and N-Ras. Mutation in $K-R A S$ gene has been detected in intestinal type of $\mathrm{GC}^{[87]}$. Moreover, mutations in $K-R A S$ gene in H. pylori-associated chronic gastritis is more frequent in GC patients than those who did not have cancer. This finding suggests that $K-R A S$ gene mutation is involved in the early stages of gastric carcinogenesis of the intestinal type ${ }^{[88]}$. Besides, fluorescent in situ hybridization study on gastric tumors, cell lines, and patients-derived xenografts shows the amplification of RTK/Ras components, including FGFR (fibroblast growth factor receptor) 2, HER2, and K-Ras ${ }^{[89]}$. 
Table 5. Genetic alteration targets for treatment of GC

\begin{tabular}{|c|c|c|c|c|}
\hline Gene & Function & Expression in GC & Treatment & Reference \\
\hline HER2 & Regulation of cell growth and differentiation, & Over, Amp & Trastuzumab & [97] \\
\hline$E G F R$ & Cell growth, cell profilation, and cellular survival & Over, Amp & $\begin{array}{c}\text { Cetuximab } \\
\text { Nimotuzumab }\end{array}$ & {$[103,104]$} \\
\hline MET & Embryogenesis, cellular survival, and cellular migration & Over, Amp & Onartuzumab & {$[102]$} \\
\hline$H G F$ & $\begin{array}{l}\text { Regulation of cell motility and cell growth, morphogenesis of } \\
\text { numerous cells and tissues, and angiogenesis }\end{array}$ & Over & Rilotumumab & [101] \\
\hline$V E G F$ & $\begin{array}{l}\text { Angiogenesis, bone formation, hematopoiesis, wound healing, } \\
\text { and development }\end{array}$ & Over & Bevacizumab & [128] \\
\hline$V E G F R 2$ & $\begin{array}{l}\text { Tyrosine kinase receptor, angiogenesis, embryonic hemopoiesis, } \\
\text { regulation of cell profilation, and organization of ECM }\end{array}$ & Over & Ramucirumab & [99] \\
\hline$F G F R 2$ & $\begin{array}{l}\text { Cell division, cell growth, formation of blood vessels, wound } \\
\text { healing, and embryonic development }\end{array}$ & Over, Amp & AZD4547 & {$[100]$} \\
\hline$I G F R$-IR & Cell growth & Over & Figitumumab & [129] \\
\hline$N F-\kappa B$ & Immune response to infection & Over & Bortezomib & [130] \\
\hline mTOR & Cell growth, cell proliferation, and cell cycle & Over & Everolimus & [131] \\
\hline$M M P s$ & Degradation and destruction of ECM & Over & Marimastat & [132] \\
\hline
\end{tabular}

Over, overexpression; Amp, amplification

\section{Nuclear factor-kB}

NF-kB is a family of bipartite transcription factors that include NFKB1, NFKB2, c-Rel, RelA, and RelB. The common form of NF-kB in mammalian is RelA/NFkB1 dimer. Activation of this pathway occurs during inflammation. NF-kB normally binds to its inhibitor, inhibitory proteins of $\mathrm{kB}$ family $(I k B)$, which leads to NF-kB being restricted in the cytoplasm. During inflammation, IkB kinase complex phosphorylates $\mathrm{IkB}$, and then the degradation of $\mathrm{IkB}$ and activation of NF-kB occur ${ }^{[90]}$. H. pylori infection induces NF-kB activation in GC. Besides, $H$. pylori infection induces the expression of the proinflammatory cytokine IL-8 through the activation of the NF-kB ${ }^{[91]}$. HuR, a RNA-binding factor, is a direct transcript target of NF-kB and its activation in GC cell lines depends on phosphatidylinositol 3-kinase/ AKT signaling. HuR activation has proliferative and anti-apoptotic effects on $\mathrm{GC}^{[92]}$. Fructose-1,6bisphosphatase-1 is an antagonist of the glycolysis process. The NF-kB is involved in glycolsis process through downregulation of FBP1 expression in $\mathrm{GC}^{[93]}$. Furthermore, the aberrant expression of NF-kB has anti-apoptotic effects and leads to drug resistant in $\mathrm{GC}^{[94,95]}$.

\section{Treatment of gastric cancer}

Surgery is the only curative treatment of GC, whereas perioperative and adjuvant chemotherapy, in addition to chemoradiation can improve the outcome of resectable GC with extended lymph node dissection.

According to the National Comprehensive Cancer Network (NCCN), the treatment of the early stages of GC guidelines includes endoscopic resection or complete surgical resection for long-term survival. Furthermore, in advanced stages of GC, the treatment includes preoperative chemotherapy, or chemoradiotherapy after surgery. The patients who have extended lymph node resection (D2) are recommended to have postoperative chemoradiation or chemotherapy. The recommendation for patients who have unresectable tumors is treating with fluoropyrimidine- or taxanebased chemoradiotherapy ${ }^{[96]}$.

There are several genes with altered expression pattern in GC that can be a target for cancer-therapy (Table 5). Trastuzumab, a humanized anti-HER2 monoclonal antibody, is used against HER2-positive $\mathrm{GCs}^{[97]}$. Cetuximab, an anti-EGFR monoclonal antibody, cannot induce any response in GC when used alone. It is shown that VEGF and their receptors are overexpressed in $\mathrm{GC}^{[98]}$. In this regard, Ramucirumab, a fully human IgG1 antibody against VEGFR2, is now approved by FDA for the treatment $\mathrm{GC}^{[99]}$.

AZD4547, as a selective ATP-competitive receptor tyrosine kinase inhibitor of FGFR, is effective against patients who have amplification of FGFR $2^{[100]}$. Furthermore, hepatocyte growth factor (rilotumumab, a fully human $\mathrm{IgG} 2$ monoclonal antibody against HGF), hepatocyte growth factor receptor (onartuzumab, humanized monoclonal antibody directed against 
HGFR), and EGFR (cetuximab, an anti-EGFR monoclonal antibody and a nimotuzumab that is a humanized monoclonal $\mathrm{IgG}_{1}$ antibody to EGFR), are also the targets of treatment in $\mathrm{GC}^{\text {[101-104] }}$.

Here, we summarized multiple pathways involving in GC carcinogenesis. A better understanding of molecular mechanisms of GC progression and development, as well as crosstalk between signaling pathways can help to identify new targets for anticancer drugs. Although many studies have been done on GC, the mechanism of GC carcinogenesis is still unclear. Understanding the molecular processes of GC could help to design more efficient genetic studies. With the novel technology advances, it will be easier to find new and useful targets in signaling pathways; these targets will be a potential marker for the early diagnosis and treatment of GC. Therefore, the management and the efficiency of treatment in patients with GC will be improved in future.

\section{ACKNOWLEDGMENTS}

This work was supported by a grant from the Vice Chancellor for Research at Mashhad University of Medical Sciences (Mashhad, Iran) and is a part of a M.Sc. student's dissertation, No. 940720.

CONFLICT OF INTEREST. None declared.

\section{REFERENCES}

1. Torre LA, Bray F, Siegel RL, Ferlay J, Lortet-Tieulent J, Jemal A. Global cancer statistics, 2012. CA: a cancer journal for clinicians 2015; 65(2): 87-108.

2. Tan P, Yeoh KG. Genetics and molecular pathogenesis of gastric adenocarcinoma. Gastroenterology 2015; 149(5): 1153-1162.

3. Bowles MJ, Benjamin IS. Cancer of the stomach and pancreas. The BMJ 2001; 323(7326): 1413-1416.

4. Jemal A, Bray F, Center MM, Ferlay J, Ward E, Forman D. Global cancer statistics. CA: a cancer journal for clinicians 2011; 61(2): 69-90.

5. Nagini S. Carcinoma of the stomach: A review of epidemiology, pathogenesis, molecular genetics and chemoprevention. World journal of gastrointestinal oncology 2012; 4(7): 156-169.

6. The Cancer Genome Atlas Research Network. Comprehensive molecular characterization of gastric adenocarcinoma. Nature 2014; 513(7517): 202-209.

7. Catalano V, Labianca R, Beretta GD, Gatta G, De Braud F, Van Cutsem E. Gastric cancer. Critical reviews in oncology/hematology 2009; 71(2): 127-164.

8. Oliveira C, Senz J, Kaurah P, Pinheiro H, Sanges R, Haegert A, Corso G, Schouten J, Fitzgerald R,
Vogelsang H, Keller G, Dwerryhouse S, Grimmer D, Chin SF, Yang HK, Jackson CE, Seruca R, Roviello F, Stupka E, Caldas C, Huntsman D. Germline CDH1 deletions in hereditary diffuse gastric cancer families. Human molecular genetics 2009; 18(9): 1545-1555.

9. Thrumurthy SG, Chaudry MA, Hochhauser D, Mughal $M$. The diagnosis and management of gastric cancer. The BMJ 2013; 347: f6367

10. Pasca di Magliano MP, Hebrok M. Hedgehog signalling in cancer formation and maintenance. Nature reviews cancer 2003; 3(12): 903-911.

11. Kim JH, Choi YJ, Lee SH, Shin HS, Lee IO, Kim YJ, Kim H, Yang WI, Kim H, Lee YC. Effect of Helicobacter pylori infection on the sonic hedgehog signaling pathway in gastric cancer cells. Oncology reports 2010; 23(6): 1523-1528.

12. Najafi M, Abbaszadegan MR, Rad A, Dastpak M, Boroumand-Noughabi S, Forghanifard MM. Crosstalk between SHH and stemness state signaling pathways in esophageal squamous cell carcinoma. Journal of cell communication and signaling 2017; 11(2): 147-153.

13. MacDonald BT, Tamai K, He X. Wnt/ $\beta$-catenin signaling: components, mechanisms, and diseases. Developmental cell 2009; 17(1): 9-26.

14. Nojima M, Suzuki H, Toyota M, Watanabe Y, Maruyama R, Sasaki S, Sasaki Y, Mita H, Nishikawa N, Yamaguchi K, Hirata K, Itoh F, Tokino T, Mori M, Imai $\mathrm{K}$, Shinomura Y. Frequent epigenetic inactivation of SFRP genes and constitutive activation of Wnt signaling in gastric cancer. Oncogene 2007; 26(32): 4699-4713.

15. Ooi CH, Ivanova T, Wu J, Lee M, Tan IB, Tao J, Ward L, Koo JH, Gopalakrishnan V, Zhu Y, Cheng LL, Lee J, Rha SY, Chung HC, Ganesan K, So J, Soo KC, Lim D, Chan WH, Wong WK, Bowtell D, Yeoh KG, Grabsch H, Boussioutas A, Tan P. Oncogenic pathway combinations predict clinical prognosis in gastric cancer. PLoS Genet 2009; 5(10): e1000676.

16. Zhang L, Xu Z, Xu X, Zhang B, Wu H, Wang M, Zhang X, Yang T, Cai J, Yan Y, Mao F, Zhu W, Shao Q, Qian $\mathrm{H}, \mathrm{Xu}$ W. SALL4, a novel marker for human gastric carcinogenesis and metastasis. Oncogene 2014; 33(48): 5491-5500.

17. Forghanifard MM, Khales SA, Javdani-Mallak A, Rad A, Farshchian M, Abbaszadegan MR. Stemness state regulators SALL4 and SOX2 are involved in progression and invasiveness of esophageal squamous cell carcinoma. Medical oncology 2014; 31(4): 1-8.

18. Forghanifard MM, Moghbeli M, Raeisossadati R, Tavassoli A, Mallak AJ, Boroumand-Noughabi S, Abbaszadegan MR. Role of SALL4 in the progression and metastasis of colorectal cancer. Journal of biomedical science 2013; 20(1): 6

19. Murata-Kamiya N, Kurashima Y, Teishikata Y, Yamahashi Y, Saito Y, Higashi H, Aburatani H, Akiyama T, Peek Jr. RM, Azuma T, Hatakeyama M. Helicobacter pylori CagA interacts with E-cadherin and deregulates the $\beta$-catenin signal that promotes intestinal transdifferentiation in gastric epithelial cells. Oncogene 2007; 26(32): 4617-4626.

20. Nakayama M, Hisatsune J, Yamasaki E, Isomoto H, 
Kurazono H, Hatakeyama M, Azuma T, Yamaoka Y, Yahiro K, Moss J, Hirayama T. Helicobacter pylori VacA-induced inhibition of GSK3 through the PI3K/Akt signaling pathway. Journal of biological chemistry 2009; 284(3): 1612-1619.

21. Yong X, Tang B, Xiao YF, Xie R, Qin Y, Luo G, Hu CJ, Dong H, Yang SM. Helicobacter pylori upregulates Nanog and Oct4 via Wnt/ $\beta$-catenin signaling pathway to promote cancer stem cell-like properties in human gastric cancer. Cancer letters 2016; 374(2): 292-303.

22. Huang $H$, Chen $Z$, Ni $X$. Tissue transglutaminase-1 promotes stemness and chemoresistance in gastric cancer cells by regulating $\mathrm{Wnt} / \beta$-catenin signaling. Experimental biology and medicine (Maywood) 2017; 242(2): 194-202.

23. Arici D, Tuncer E, Ozer H, Simek G, Koyuncu A. Expression of retinoblastoma and cyclin D1 in gastric carcinoma. Neoplasma 2008; 56(1): 63-67.

24. Hirata Y, Maeda S, Mitsuno Y, Akanuma M, Yamaji Y, Ogura K, Yoshida H, Shiratori Y, Omata M. Helicobacter pylori activates the cyclin D1 gene through mitogen-activated protein kinase pathway in gastric cancer cells. Infection and immunity 2001; 69(6): 3965-3971.

25. Fenoglio-Preiser CM, Wang J, Stemmermann G, Noffsinger A. TP53 and gastric carcinoma: a review. Human mutation 2003; 21(3): 258-270.

26. Gamboa-Dominguez A, Seidl S, Reyes-Gutierrez E, Hermannstädter C, Quintanilla-Martinez L, Busch R, Höfler H, Fend F, Luber B. Prognostic significance of p21WAF1/CIP1, p27Kip1, p53 and E-cadherin expression in gastric cancer. Journal of clinical pathology 2007; 60(7): 756-761.

27. Nitti D, Belluco C, Mammano E, Marchet A, Ambrosi A, Mencarelli R, Segato P, Lise M. Low level of p27 (Kip1) protein expression in gastric adenocarcinoma is associated with disease progression and poor outcome. Journal of surgical oncology 2002; 81(4): 167-175.

28. Abbaszadegan MR, Moaven O, Sima HR, Ghafarzadegan K, A'rabi A, Forghani MN, Raziee HR, Mashhadinejad A, Jafarzadeh M, Esmaili-Shandiz E, Dadkhah E. p16 promoter hypermethylation: a useful serum marker for early detection of gastric cancer. World journal of gastroenterology 2008; 14(13): 20552060.

29. Kopan R, Ilagan MXG. The canonical Notch signaling pathway: unfolding the activation mechanism. Cell 2009; 137(2): 216-233.

30. Yeh TS, Wu CW, Hsu KW, Liao WJ, Yang MC, Li AF, Wang AM, Kuo ML, Chi CW. The activated Notch1 signal pathway is associated with gastric cancer progression through cyclooxygenase-2. Cancer research 2009; 69(12): 5039-5048.

31. Sun Y, Gao X, Liu J, Kong QY, Wang XW, Chen XY, Wang Q, Cheng YF, Qu XX, Li H. Differential Notch1 and Notch2 expression and frequent activation of Notch signaling in gastric cancers. Archives of pathology and laboratory medicine 2011; 135(4): 451-458.

32. Kang H, An HJ, Song JY, Kim TH, Heo JH, Ahn DH, Kim G. Notch3 and Jagged2 contribute to gastric cancer development and to glandular differentiation associated with MUC2 and MUC5AC expression. Histopathology 2012; 61(4): 576-586.

33. Kim S, Lee H, Baek J, Cho Y, Kang H, Jeong J, Song J, Park H, Chun K. Activation of nuclear PTEN by inhibition of Notch signaling induces $\mathrm{G} 2 / \mathrm{M}$ cell cycle arrest in gastric cancer. Oncogene 2016; 35(2): 251-260.

34. Forghanifard MM, Taleb S, Abbaszadegan MR. Notch signaling target genes are directly correlated to esophageal squamous cell carcinoma tumorigenesis. Pathology and oncology research 2015; 21(2): 463-467.

35. Zhou GX, Li XY, Zhang Q, Zhao K, Zhang CP, Xue $\mathrm{CH}$, Yang $\mathrm{K}$, Tian ZB. Effects of the hippo signaling pathway in human gastric cancer. Asian Pacific journal of cancer prevention 2013; 14(9): 5199-5205.

36. Lei QY, Zhang H, Zhao B, Zha ZY, Bai F, Pei XH, Zhao S, Xiong Y, Guan KL. TAZ promotes cell proliferation and epithelial-mesenchymal transition and is inhibited by the hippo pathway. Molecular and cellular biology 2008; 28(7): 2426-2436.

37. Lam-Himlin DM, Daniels JA, Gayyed MF, Dong J, Maitra A, Pan D, Montgomery EA, Anders RA. The hippo pathway in human upper gastrointestinal dysplasia and carcinoma: a novel oncogenic pathway. Journal of gastrointestinal cancer 2006; 37(4): 103-109.

38. Deng J, Lei W, Xiang X, Zhang L, Yu F, Chen J, Feng M, Xiong J. MicroRNA-506 inhibits gastric cancer proliferation and invasion by directly targeting Yap1. Tumor biology 2015; 36(9): 6823-6831.

39. Kakiuchi M, Nishizawa T, Ueda H, Gotoh K, Tanaka A, Hayashi A, Yamamoto S, Tatsuno K, Katoh H, Watanabe Y, Ichimura T, Ushiku T, Funahashi S, Tateishi K, Wada I, Shimizu N, Nomura S, Koike K, Seto Y, Fukayama M, Aburatani H, Ishikawa S. Recurrent gain-of-function mutations of RHOA in diffuse-type gastric carcinoma. Nature genetics 2014; 46(6): 583-587.

40. Lim B, Park JL, Kim HJ, Park YK, Kim JH, Sohn HA, Noh SM, Song KS, Kim WH, Kim YS, Kim SY. Integrative genomics analysis reveals the multilevel dysregulation and oncogenic characteristics of TEAD4 in gastric cancer. Carcinogenesis 2014; 35(5): 10201027.

41. Sun L, Chen F, Shi W, Qi L, Zhao Z, Zhang J. Prognostic impact of TAZ and $\beta$-catenin expression in adenocarcinoma of the esophagogastric junction. Diagnostic pathology 2014; 9: 125.

42. Thiery JP, Sleeman JP. Complex networks orchestrate epithelial-mesenchymal transitions. Nature reviews molecular cell biology 2006; 7(2): 131-142.

43. Kalluri R, Weinberg RA. The basics of epithelialmesenchymal transition. The Journal of clinical investigation 2009; 119(6): 1420-1428.

44. Valdés F, Álvarez AM, Locascio A, Vega S, Herrera B, Fernández M, Benito M, Nieto MA, Fabregat I. The epithelial mesenchymal transition confers resistance to the apoptotic effects of transforming growth factor $\beta$ in fetal rat hepatocytes. Molecular cancer research 2002; 1(1): 68-78.

45. Qiao Y, Jiang X, Lee ST, Karuturi RM, Hooi SC, Yu Q. 
FOXQ1 regulates epithelial-mesenchymal transition in human cancers. Cancer research 2011; 71(8): 30763086.

46. Zeisberg M, Neilson EG. Biomarkers for epithelialmesenchymal transitions. The journal of clinical investigation 2009; 119(6): 1429-1437.

47. Kanzawa M, Semba S, Hara S, Itoh T, Yokozaki H. WNT5A is a key regulator of the epithelialmesenchymal transition and cancer stem cell properties in human gastric carcinoma cells. Pathobiology 2013; 80(5): 235-244.

48. Guo J, Fu Z, Wei J, Lu W, Feng J, Zhang S. PRRX1 promotes epithelial-mesenchymal transition through the Wnt/ $\beta$-catenin pathway in gastric cancer. Medical oncology 2015; 32(1): 393.

49. Yu H, Zeng J, Liang X, Wang W, Zhou Y, Sun Y, Liu S, Li W, Chen C, Jia J. Helicobacter pylori promotes epithelial-mesenchymal transition in gastric cancer by downregulating programmed cell death protein 4 (PDCD4). PloS one 2014; 9(8): e105306.

50. Liu AN, Zhu ZH, Chang SJ, Hang XS. Twist expression associated with the epithelial-mesenchymal transition in gastric cancer. Molecular and cellular biochemistry 2012; 367(1-2): 195-203.

51. Huang J, Xiao D, Li G, Ma J, Chen P, Yuan W, Hou F, Ge J, Zhong M, Tang Y, Xia X, Chen Z. EphA2 promotes epithelial-mesenchymal transition through the Wnt/ $\beta$-catenin pathway in gastric cancer cells. Oncogene 2014; 33(21): 2737-2747.

52. Zheng H, Li W, Wang Y, Liu Z, Cai Y, Xie T, Shi M, Wang Z, Jiang B. Glycogen synthase kinase-3 beta regulates Snail and $\beta$-catenin expression during Fasinduced epithelial-mesenchymal transition in gastrointestinal cancer. European journal of cancer 2013; 49(12): 2734-2746.

53. Choi YJ, Kim N, Chang H, Lee HS, Park SM, Park JH, Shin CM, Kim JM, Kim JS, Lee DH. Helicobacter pylori-induced epithelial-mesenchymal transition, a potential role of gastric cancer initiation and an emergence of stem cells. Carcinogenesis 2015; 36(5): 553-563.

54. Ryu HS, Park DJ, Kim HH, Kim WH, Lee HS. Combination of epithelial-mesenchymal transition and cancer stem cell-like phenotypes has independent prognostic value in gastric cancer. Human pathology 2012; 43(4): 520-528.

55. Forghanifard MM, Moaven O, Farshchian M, Montazer M, Raeisossadati R, Abdollahi A, Moghbeli M, Nejadsattari T, Parivar K, Abbaszadegan MR. Expression analysis elucidates the roles of MAML1 and Twist1 in esophageal squamous cell carcinoma aggressiveness and metastasis. Annals of surgical oncology 2012; 19(3): 743-749.

56. Forghanifard MM, Khales SA, Farshchian M, Rad A, Homayouni-Tabrizi M, Abbaszadegan MR. Negative regulatory role of TWIST1 on SNAIL gene expression. Pathology and oncology research 2017; 23(1): 85-90.

57. Roy R, Yang J, Moses MA. Matrix metalloproteinases as novel biomarker s and potential therapeutic targets in human cancer. Journal of clinical oncology 2009;
27(31): 5287-5297.

58. Chen SZ, Yao HQ, Zhu SZ, Li QY, Guo GH, Yu J. Expression levels of matrix metalloproteinase-9 in human gastric carcinoma. Oncology letters 2015; 9(2): 915-919.

59. Sier C, Kubben FJ, Ganesh S, Heerding MM, Griffioen $\mathrm{G}$, Hanemaaijer R, Van Krieken JH, Lamers CB, Verspaget HW. Tissue levels of matrix metalloproteinases MMP-2 and MMP-9 are related to the overall survival of patients with gastric carcinoma. British journal of cancer 1996; 74(3): 413-417.

60. Inoue T, Yashiro M, Nishimura S, Maeda K, Sawada T, Ogawa Y, Sowa M, Chung K. Matrix metalloproteinase1 expression is a prognostic factor for patients with advanced gastric cancer. International journal of molecular medicine 1999; 4(1): 73-77.

61. Lian PL, Liu Z, Yang GY, Zhao R, Zhang ZY, Chen YG, Zhuang ZN, Xu KS. Integrin $\alpha v \beta 6$ and matrix metalloproteinase 9 correlate with survival in gastric cancer. World journal of gastroenterology 2016; 22(14): 3852-3859.

62. Katz LH, Li Y, Chen JS, Muñoz NM, Majumdar A, Chen J, Mishra L. Targeting TGF- $\beta$ signaling in cancer. Expert opinion on therapeutic targets 2013; 17(7): 743760.

63. Miyazono K, Suzuki H, Imamura T. Regulation of TGF- $\beta$ signaling and its roles in progression of tumors. Cancer science 2003; 94(3): 230-234.

64. Ananiev J, Manolova I, Aleksandrova E, Gulubova M. Impact of TGF- $\beta 1$ expression and-509C> T polymorphism in the TGF- $\beta 1$ gene on the progression and survival of gastric cancer. Polish journal of pathology; 68(3): 234-240.

65. Hu WQ, Wang LW, Yuan JP, Yan SG, Li JD, Zhao HL, Peng CW, Yang GF, Li Y. High expression of transform growth factor beta 1 in gastric cancer confers worse outcome: results of a cohort study on 184 patients. Hepato-gastroenterology 2014; 61(129): 245-250.

66. Ito K, Liu Q, Salto-Tellez M, Yano T, Tada K, Ida H, Huang C, Shah N, Inoue M, Rajnakova A, Peh BK, Han HC, Ito T, Teh M, Yeoh KG, Ito Y. RUNX3, a novel tumor suppressor, is frequently inactivated in gastric cancer by protein mislocalization. Cancer research 2005; 65(17): 7743-7750.

67. Katayama Y, Takahashi M, Kuwayama H. Helicobacter pylori causes runx3 gene methylation and its loss of expression in gastric epithelial cells, which is mediated by nitric oxide produced by macrophages. Biochemical and biophysical research communications 2009; 388(3): 496-500.

68. Powell SM, Harper JC, Hamilton SR, Robinson CR, Cummings OW. Inactivation of Smad4 in gastric carcinomas. Cancer research 1997; 57(19): 4221-4224.

69. Kim JJ, Baek MJ, Kim L, Kim NG, Lee YC, Song SY, Noh SH, Kim H. Accumulated frameshift mutations at coding nucleotide repeats during the progression of gastric carcinoma with microsatellite instability. Laboratory investigation 1999; 79(9): 1113-1120.

70. Kang SH, Bang YJ, Im YH, Yang HK, Lee DA, Lee HY, Lee HS, Kim NK, Kim SJ. Transcriptional 
repression of the transforming growth factor- $\beta$ type I receptor gene by DNA methylation results in the development of TGF- $\beta$ resistance in human gastric cancer. Oncogene 1999; 18(51): 7280-7286.

71. Kargman S, Charleson S, Cartwright M, Frank J, Riendeau D, Mancini J, Evans J, O'Neill G. Characterization of prostaglandin $\mathrm{G} / \mathrm{H}$ synthase 1 and 2 in rat, dog, monkey, and human gastrointestinal tracts. Gastroenterology 1996; 111(2): 445-454.

72. Ristimäki A, Honkanen N, Jänkälä H, Sipponen P, Härkönen M. Expression of cyclooxygenase-2 in human gastric carcinoma. Cancer research 1997; 57(7): 12761280.

73. Uefuji K, Ichikura $\mathrm{T}$, Mochizuki H. Expression of cyclooxygenase- 2 in human gastric adenomas and adenocarcinomas. Journal of surgical oncology 2001; 76(1): 26-30

74. Ohno R, Yoshinaga K, Fujita T, Hasegawa K, Iseki H, Tsunozaki H, Ichikawa W, Nihei Z, Sugihara K. Depth of invasion parallels increased cyclooxygenase-2 levels in patients with gastric carcinoma. Cancer 2001; 91(10): 1876-1881

75. Li Q, Liu N, Shen B, Zhou L, Wang Y, Wang Y, Sun J, Fan Z, Liu RH. Helicobacter pylori enhances cyclooxygenase 2 expression via p38MAPK/ATF-2 signaling pathway in MKN45 cells. Cancer letters 2009; 278(1): 97-103

76. Caputo R, Tuccillo C, Manzo BA, Zarrilli R, Tortora G, Blanco CDV, Ricci V, Ciardiello F, Romano M. Helicobacter pylori VacA toxin up-regulates vascular endothelial growth factor expression in MKN 28 gastric cells through an epidermal growth factor receptor-, cyclooxygenase-2-dependent mechanism. Clinical cancer research 2003; 9(6): 2015-2021

77. Huang S-P, Wu M-S, Shun C-T, Wang H-P, Hsieh C-Y, Kuo M-L, Lin J-T. Cyclooxygenase-2 increases hypoxia-inducible factor-1 and vascular endothelial growth factor to promote angiogenesis in gastric carcinoma. Journal of biomedical science 2005; 12(1): 229-241

78. Ye Y, Liu M, Yuan H, Ning S, Wang Y, Chen Z, Ji R, Guo Q, Li Q, Zhou Y. COX-2 regulates Snail expression in gastric cancer via the Notch1 signaling pathway. International journal of molecular medicine 2017; 40(2): 512-522

79. Henderson WR. The role of leukotrienes in inflammation. Annals of internal medicine 1994; 121(9): 684-697

80. Chen F-L, Wang X-Z, Li J-Y, Yu J-P, Huang C-Y, Chen Z-X. 12-lipoxygenase induces apoptosis of human gastric cancer AGS cells via the ERK1/2 signal pathway. Digestive diseases and sciences 2008; 53(1): 181-187

81. Wong BCY, Wang WP, Cho CH, Fan XM, Lin MCM, Kung HF, Lam SK. 12-Lipoxygenase inhibition induced apoptosis in human gastric cancer cells. Carcinogenesis 2001; 22(9): 1349-1354

82. Zou L-Y, Li J-Y, Chen F-L, Chen Z-X, Wang X-Z. Tumor 5-lipoxygenase expression correlates with gastric cancer metastasis and its selective inhibitor induces cancer cell apoptosis. Journal of Cancer Molecules 2006; 2(6): 227-233

83. Park S, Yeo M, Jin J-H, Lee K-M, Kim SS, Choi SY, Hahm K-B. Inhibitory activities and attenuated expressions of 5-LOX with red ginseng in Helicobacter pylori-infected gastric epithelial cells. Digestive diseases and sciences 2007; 52(4): 973-982

84. Fan XM, Tu SP, Lam SK, Wang WP, Wu J, Wong WM, Yuen MF, Lin MCM, Kung HF, WONG BCY. Five-lipoxygenase-activating protein inhibitor MK-886 induces apoptosis in gastric cancer through upregulation of p27kip1 and bax. Journal of gastroenterology and hepatology 2004; 19(1): 31-37

85. Matsubara J, Yamada Y, Hirashima Y, Takahari D, Okita NT, Kato K, Hamaguchi T, Shirao K, Shimada Y, Shimoda T. Impact of insulin-like growth factor type 1 receptor, epidermal growth factor receptor, and HER2 expressions on outcomes of patients with gastric cancer. Clinical cancer research 2008; 14(10): 3022-3029.

86. Gravalos C, Jimeno A. HER2 in gastric cancer: a new prognostic factor and a novel therapeutic target. Annals of oncology 2008; 19(9): 1523-1529.

87. Miki H, Ohmori M, Perantoni A, Enomoto T. K-ras activation in gastric epithelial tumors in Japanese. Cancer letters 1991; 58(1): 107-113.

88. Gong C, Mera R, Bravo JC, Ruiz B, Diaz-Escamilla R, Fontham ET, Correa P, Hunt JD. KRAS mutations predict progression of preneoplastic gastric lesions. Cancer epidemiology biomarkers and prevention 1999; 8(2): 167-171.

89. Das K, Gunasegaran B, Tan IB, Deng N, Lim KH, Tan P. Mutually exclusive FGFR2, HER2, and KRAS gene amplifications in gastric cancer revealed by multicolour FISH. Cancer letters 2014; 353(2): 167-175.

90. Spehlmann ME, Eckmann L. Nuclear factor-kappa B in intestinal protection and destruction. Current opinion in gastroenterology 2009; 25(2): 92-99.

91. Sharma SA, Tummuru MKR, Blaser MJ, Kerr LD. Activation of IL-8 gene expression by Helicobacter pylori is regulated by transcription factor nuclear factor$\kappa \mathrm{B}$ in gastric epithelial cells. The journal of immunology 1998; 160(5): 2401-2407.

92. Kang MJ, Ryu BK, Lee MG, Han J, Lee JH, Ha TK, Byun DS, Chae KS, Lee BH, Chun HS, Lee KY, Kim HJ, Chi SG. NF- $\kappa B$ activates transcription of the RNAbinding factor $\mathrm{HuR}$, via PI3K-AKT signaling, to promote gastric tumorigenesis. Gastroenterology 2008; 135(6): 2030-2042. e2033.

93. Liu X, Wang X, Zhang J, Lam E, Shin VY, Cheng AS, Yu J, Chan FK, Sung JJ, Jin HC. Warburg effect revisited: an epigenetic link between glycolysis and gastric carcinogenesis. Oncogene 2010; 29(3): 442-450.

94. Liu CA, Wang MJ, Chi CW, Wu Cw, Chen JY. Rho/Rhotekin-mediated NF-kappaB activation confers resistance to apoptosis. Oncogene 2004; 23(54): 87318742.

95. Cho SJ, Park JW, Kang JS, Kim WH, Juhnn YS, Lee JS, Kim YH, Ko YS, Nam SY, Lee BL. Nuclear factor- $\kappa B$ dependency of doxorubicin sensitivity in gastric cancer cells is determined by manganese superoxide dismutase 
expression. Cancer science 2008; 99(6): 1117-1124.

96. Ajani JA, Bentrem DJ, Besh S, D'Amico TA, Das P, Denlinger C, Fakih MG, Fuchs CS, Gerdes H, Glasgow RE, Hayman JA, Hofstetter WL, Ilson DH, Keswani RN, Kleinberg LR, Korn WM, Lockhart AC, Meredith K, Mulcahy MF, Orringer MB, Posey JA, Sasson AR, Scott WJ, Strong VE, Varghese TK Jr, Warren G, Washington MK, Willett C, Wright CD, McMillian NR, Sundar H, National Comprehensive Cancer Network. Gastric cancer, version 2.2013: featured updates to the NCCN guidelines. Journal of the national comprehensive cancer network 2013; 11(5): 531-546.

97. Bang YJ, Van Cutsem E, Feyereislova A, Chung HC, Shen L, Sawaki A, Lordick F, Ohtsu A, Omuro Y, Satoh T, Aprile G, Kulikov E, Hill J, Lehle M, Rüschoff J, Kang YK; ToGA Trial Investigators. Trastuzumab in combination with chemotherapy versus chemotherapy alone for treatment of HER2-positive advanced gastric or gastro-oesophageal junction cancer (ToGA): a phase 3, open-label, randomised controlled trial. The Lancet 2010; 376(9742): 687-697.

98. Hirashima Y, Yamada Y, Matsubara J, Takahari D, Okita N, Takashima A, Kato K, Hamaguchi T, Shirao $\mathrm{K}$, Shimada Y, Taniguchi H, Shimoda T. Impact of vascular endothelial growth factor receptor 1, 2, and 3 expression on the outcome of patients with gastric cancer. Cancer science 2009; 100(2): 310-315.

99. Fuchs CS, Tabernero J, Tomasek J, Chau I, Melichar B, Safran H, Tehfe MA, Dumitru F, Topuzov E, Schlittler L, Anghel Adrian Udrea, William Campbell, Stephen Brincat, Michael Emig, Symantha A. Melemed, Rebecca R. Hozak, David Ferry, William Caldwell, Jaffer A. Ajani. Candidate biomarker analyses in gastric or gastro-esophageal junction carcinoma: REGARD trial of single-agent ramucirumab (RAM) vs. placebo (PL). Journal of clinical oncology; 15(May 20 2015): 4029.

100. Xie L, Su X, Zhang L, Yin X, Tang L, Zhang X, Xu Y, Gao Z, Liu K, Zhou M, Gao B, Shen D, Zhang L, Ji J, Gavine PR, Zhang J, Kilgour E, Zhang X, Ji Q. FGFR2 gene amplification in gastric cancer predicts sensitivity to the selective FGFR inhibitor AZD4547. Clinical cancer research 2013; 19(9): 2572-2583.

101. Iveson T, Donehower RC, Davidenko I, Tjulandin S, Deptala A, Harrison M, Nirni S, Lakshmaiah K, Thomas A, Jiang Y, Zhu M, Tang R, Anderson A, Dubey S, Onliner KS, Loh E. Rilotumumab in combination with epirubicin, cisplatin, and capecitabine as first-line treatment for gastric or oesophagogastric junction adenocarcinoma: an open-label, dose de-escalation phase $1 \mathrm{~b}$ study and a double-blind, randomised phase 2 study. The lancet oncology 2014; 15(9): 1007-1018.

102. Shah MA, Bang YJ, Lordick F, Tabernero J, Chen M, Hack SP, Phan SC, Shames DS, Cunningham D. METGastric: A phase III study of onartuzumab plus mFOLFOX6 in patients with metastatic HER2-negative (HER2-) and MET-positive (MET+) adenocarcinoma of the stomach or gastroesophageal junction (GEC). Journal of clinical oncology; 15(May 20 2015): 4012.

103. Lordick F, Kang YK, Chung HC, Salman P, Oh SC,
Bodoky G, Kurteva G, Volovat C, Moiseyenko VM, Gorbunova V, Park JO, Sawaki A, Celik I, Götte H, Melezínková H, Moehler M, Arbeitsgemeinschaft Internistische Onkologie and EXPAND Investigators. Capecitabine and cisplatin with or without cetuximab for patients with previously untreated advanced gastric cancer (EXPAND): a randomised, open-label phase 3 trial. The lancet oncology 2013; 14(6): 490-499.

104. Satoh T, Lee KH, Rha SY, Sasaki Y, Park SH, Komatsu Y, Yasui H, Kim TY, Yamaguchi K, Fuse N, Yasuhide Yamada, Takashi Ura, Si-Young Kim, Masaki Munakata, Soh Saitoh, Kazuto Nishio, Satoshi Morita, Eriko Yamamoto, Qingwei Zhang, Jung-mi Kim, Yeul Hong Kim, Yuh Sakata. Randomized phase II trial of nimotuzumab plus irinotecan versus irinotecan alone as second-line therapy for patients with advanced gastric cancer. Gastric cancer 2015; 18(4): 824-832.

105. Nardone G, Compare D. Epigenetic alterations due to diet and Helicobacter pylori infection in gastric carcinogenesis. Expert review of gastroenterology and hepatology 2008; 2(2): 243-248.

106. Nomura AM, Wilkens LR, Henderson BE, Epplein M, Kolonel LN. The association of cigarette smoking with gastric cancer: the multiethnic cohort study. Cancer causes and control 2012; 23(1): 51-58.

107. Fitzgerald RC, Hardwick R, Huntsman D, Carneiro F, Guilford P, Blair V, Chung DC, Norton J, Ragunath K, Van Krieken JH, Dwerryhouse S, Caldas C, International Gastric Cancer Linkage Consortium. Hereditary diffuse gastric cancer: updated consensus guidelines for clinical management and directions for future research. Journal of medical genetics 2010; 47(7): 436-444.

108. Boysen T, Mohammadi M, Melbye M, Hamilton-Dutoit S, Vainer B, Hansen A, Wohlfahrt J, Friborg J. EBVassociated gastric carcinoma in high-and low-incidence areas for nasopharyngeal carcinoma. British journal of cancer 2009; 101(3): 530-533.

109. Fukaya M, Isohata N, Ohta H, Aoyagi K, Ochiya T, Saeki N, Yanagihara K, Nakanishi Y, Taniguchi H, Sakamoto H, Shimoda T, Nimura Y, Yoshida T, Sasaki $\mathrm{H}$. Hedgehog signal activation in gastric pit cell and in diffuse-type gastric cancer. Gastroenterology 2006; 131(1): 14-29.

110. Yan R, Peng X, Yuan X, Huang D, Chen J, Lu Q, Lv N, Luo S. Suppression of growth and migration by blocking the Hedgehog signaling pathway in gastric cancer cells. Cellular oncology (Dordr) 2013; 36(5): 421-435.

111. Niu Y, Li F, Tang B, Shi Y, Hao Y, Yu P. Clinicopathological correlation and prognostic significance of sonic hedgehog protein overexpression in human gastric cancer. International journal of clinical and experimental pathology 2014; 7(8): 51445153.

112.Zhang C, Li C, He F, Cai Y, Yang H. Identification of CD44+ CD24+ gastric cancer stem cells. Journal of cancer research and clinical oncology 2011; 137(11): 1679-1686.

113. Mao J, Fan S, Ma W, Fan P, Wang B, Zhang J, Wang H, 
Tang B, Zhang Q, Yu X, Wang L, Song B, Li L. Roles of Wnt/ $\beta$-catenin signaling in the gastric cancer stem cells proliferation and salinomycin treatment. Cell death and disease 2014; 5(1): e1039.

114. Cheng XX, Wang ZC, Chen XY, Sun Y, Kong QY, Liu J, Li H. Correlation of Wnt-2 expression and $\beta$-catenin intracellular accumulation in Chinese gastric cancers: relevance with tumour dissemination. Cancer letters 2005; 223(2): 339-347.

115. Kurayoshi M, Oue N, Yamamoto H, Kishida M, Inoue A, Asahara T, Yasui W, Kikuchi A. Expression of Wnt$5 \mathrm{a}$ is correlated with aggressiveness of gastric cancer by stimulating cell migration and invasion. Cancer research 2006; 66(21): 10439-10448.

116. To KF, Chan MW, Leung WK, Yu J, Tong JH, Lee TL, Chan FK, Sung JJ. Alterations of frizzled (FzE3) and secreted frizzled related protein (hsFRP) expression in gastric cancer. Life sciences 2001; 70(4): 483-489.

117. Pan KF, Liu WG, Zhang L, You WC, Lu YY. Mutations in components of the Wnt signaling pathway in gastric cancer. World journal of gastroenterology 2008; 14(10): $1570-1574$

118. Kim MS, Kim SS, Ahn CH, Yoo NJ, Lee SH. Frameshift mutations of Wnt pathway genes AXIN2 and TCF7L2 in gastric carcinomas with high microsatellite instability. Human pathology 2009; 40(1): 58-64.

119. Rhyu MG, Park WS, Jung YJ, Choi SW, Meltzer SJ. Allelic deletions of MCC/APC and p53 are frequent late events in human gastric carcinogenesis. Gastroentology 1994; 106(6): 1584-1584.

120. Tong X, Li L, Li X, Heng L, Zhong L, Su X, Rong R, Hu S, Liu W, Jia B, Xing Liu, Geng Kou, Jun Han, Shangjing Guo, Yi Hu, Cheng Li, Qian Tao, Yajun Guo. SOX10, a novel HMG-box-containing tumor suppressor, inhibits growth and metastasis of digestive cancers by suppressing the $\mathrm{Wnt} / \beta$-catenin pathway. Oncotarget 2014; 5(21): 10571-10583.

121. Kirikoshi H, Sekihara H, Katoh M. Up-regulation of WNT10A by tumor necrosis factor $\alpha$ and Helicobacter pylori in gastric cancer. International journal of oncology 2001; 19(3): 533-536.

122. Murai T, Yamada S, Fuchs BC, Fujii T, Nakayama G, Sugimoto H, Koike M, Fujiwara M, Tanabe KK, Kodera Y. Epithelial-to-mesenchymal transition predicts prognosis in clinical gastric cancer. Journal of surgical oncology 2014; 109(7): 684-689.

123. Rosivatz E, Becker I, Specht K, Fricke E, Luber B, Busch R, Höfler H, Becker KF. Differential expression of the epithelial-mesenchymal transition regulators snail, SIP1, and twist in gastric cancer. The American journal of pathology 2002; 161(5): 1881-1891.

124. Shin NR, Jeong EH, Choi CI, Moon HJ, Kwon CH, Chu IS, Kim GH, Jeon TY, Kim DH, Lee JH, Park DY.
Overexpression of Snail is associated with lymph node metastasis and poor prognosis in patients with gastric cancer. BMC cancer 2012; 12: 521

125. Jia B, Liu H, Kong Q, Li B. Overexpression of ZEB1 associated with metastasis and invasion in patients with gastric carcinoma. Molecular and cellular biochemistry 2012; 366(1-2): 223-229.

126. Otsuki S, Inokuchi M, Enjoji M, Ishikawa T, Takagi Y, Kato K, Yamada H, Kojima K, Sugihara K. Vimentin expression is associated with decreased survival in gastric cancer. Oncology reports 2011; 25(5): 12351242.

127. Alves CC, Rosivatz E, Schott C, Hollweck R, Becker I, Sarbia M, Carneiro F, Becker KF. Slug is overexpressed in gastric carcinomas and may act synergistically with SIP1 and Snail in the down-regulation of E-cadherin. The Journal of pathology 2007; 211(5): 507-515.

128. Van Cutsem E, de Haas S, Kang YK, Ohtsu A, Tebbutt NC, Xu JM, Yong WP, Langer B, Delmar P, Scherer SJ, Shah MA. Bevacizumab in combination with chemotherapy as first-line therapy in advanced gastric cancer: a biomarker evaluation from the AVAGAST randomized phase III trial. Journal of clinical oncology 2012; 30(17): 2119-2127.

129. Molife L, Fong P, Paccagnella L, Reid A, Shaw HM, Vidal L, Arkenau HT, Karavasilis V, Yap TA, Olmos D, Spicer J, Postel-Vinay S, Yin D, Lipton A, Demers L, Leitzel K, Gualberto A, de Bono JS. The insulin-like growth factor-I receptor inhibitor figitumumab (CP751,871 ) in combination with docetaxel in patients with advanced solid tumours: results of a phase Ib doseescalation, open-label study. British journal of cancer 2010; 103(3): 332-339.

130.Nakata W, Hayakawa Y, Nakagawa H, Sakamoto K, Kinoshita H, Takahashi R, Hirata Y, Maeda S, Koike K. Anti-tumor activity of the proteasome inhibitor bortezomib in gastric cancer. International journal of oncology 2011; 39(6): 1529-1536.

131.Ohtsu A, Ajani JA, Bai YX, Bang YJ, Chung HC, Pan HM, Sahmoud T, Shen L, Yeh KH, Chin K, Muro K, Kim YH, Ferry D, Tebbutt NC, Al-Batran SE, Smith H, Costantini C, Rizvi S, Lebwohl D, Van Cutsem E. Everolimus for previously treated advanced gastric cancer: results of the randomized, double-blind, phase III GRANITE-1 study. Journal of Clinical Oncology 2013; 31(31): 3935-3943.

132.Bramhall S, Hallissey M, Whiting J, Scholefield J, Tierney G, Stuart RC, Hawkins RE, McCulloch P, Maughan T, Brown PD, Baillet M, Fielding JWL. Marimastat as maintenance therapy for patients with advanced gastric cancer: a randomised trial. British journal of cancer 2002; 86(12): 1864-1870. 